\title{
Building Bridges and Trust Through Interfaith Relations in Africa: The Role of African Indigenous Religious and Cultural Values
}

\author{
Francis Acquah \\ Methodist University College Ghana, Department of Educational Studies. P. O. Box DC 940, Dansoman - \\ Accra, Ghana
}

\begin{abstract}
The African continent is not a homogenous entity; it is religiously and culturally diverse. The continent's religious and cultural varieties have presented both prospects for progress and setbacks. The religious and ethnic differences and certain prevailing socio-economic structures of oppression in most societies as well as the disintegrative impact of globalization, have, sometimes, created pressures and tensions. These conditions tend to transform into situations of mistrust, stereotypes, fear of the other, exclusion, and violence, thereby diminishing Africa's efforts to make the expected progress. However, this paper argues that the innate religious disposition of African people, and their indigenous cultural values provide a common ground and a rallying point around which trust can be built to promote sustainable living and peaceful co-existence. This work recommends an interfaith approach, which takes into account and makes use of certain African indigenous religious and cultural resources in building bridges and trust for peace and sustainable living.
\end{abstract}

Keywords: Interfaith relations, religious diversities, extremism, pluralistic, bridges, trust, indigenous religious and cultural values, dialogue of life

DOI: $10.7176 / \mathrm{JAAS} / 66-06$

Publication date:July $31^{\text {st }} 2020$

\section{Introduction}

The African continent is religiously and culturally pluralistic, with over 3, 000 ethnic groups, who speak more than 2, 100 different languages. According to Pew Research Centre (2015) survey conducted in 2010, the people of Africa practise a variety of religions such as African Traditional Religions (ATRs), Judaism, Christianity, Islam, Hinduism and others. ${ }^{1}$ The diversity of the continent presents both an asset and a liability. The diverse nature of the continent's religious and cultural resources has the potential to enrich one another in their encounters. However, this has not always been the reality of the people's living situations. Rather, mistrust, stereotypes, fear of the other, exclusion and elements which divide, rather than, build peace have been stressed, sometimes, leading to conflict situations on the continent. Sarbah (2016) corroborates on this, referring to Christian-Muslim encounters in West Africa which have been characterized by instances of intolerance, tensions, and conflicts, resulting in violent clashes that have destroyed innocent life and property in places such as Nigeria, Ghana, Senegal, Mali, Sudan, and Cote d' Ivoire. Furthermore, there is a trend of terrorism which is imbued with religious character and motivations (Sampatkumar, 2004). The religious involvement in the on-going disruptions cannot be under estimated for a number of reasons. First, for black Africans, especially, religion infuses into every aspect of life. This is what (Olukpona, 1991:28) meant when he stated that, "The African experience of God is one in which the sacred and the profane tend to be symmetrical. The ordinary human experience is mimetic of the transcendence and the sacred." In African experience of life, religion provides the grounding of being and the basis of human conduct. It is in recognition of the prominent role of religion in African life that the Citizens and Diaspora Directorate (CIDO) of the African Union (AU) Commission in collaboration with King Abdullah Bin Abdulaziz Centre for Interreligious and Inter-cultural Dialogue, have instituted the African Union Interfaith Forum. The third forum took place at the Hilton Hotel, Sabanga, Chad from November 13 to 15, 2018 on the theme, "Faith in Action: The Role of Religious Leaders in Advancing Peace, Inclusiveness and Development in African Communities" (African Union Commission, 2018). ${ }^{2}$

Secondly, religion throughout human history has exhibited the capacity for violence and destructions as well as inherent resources and values for fostering harmony and peaceful co-existence. The ambivalent nature of religion has been well observed by Appleby (2000:16): "In each of the major religious traditions of the world, prophets, theologians, sages, scholars, and simple believers...refined and deepened the tradition's spiritual practices and theological and ethical teachings in support of peacemaking..." He, however, observes that some religious extremists resort to some selected scriptures and doctrines in their tradition in endorsement of violence (Appleby, 2000:17). The religious phenomenon in human affairs hardly gives communities and individuals the easy option of deciding to dismiss it outright, especially, in black Africa. Participation in the community or social life, invariably, means sharing in the religious life of that community. Magesa, (1998:33), for example, sums up the African indigenous understanding of religion as follows: "For Africans, religion is quite literally life and life 
is religion. “...African religion... is entirely a lived religion, not a doctrinal one. It requires no formal induction. One is born into it and one learns from it from childhood throughout one's life through normal socialization." This study attempts to explore an interfaith model that makes use of resources which make meaning to African experience of life to build bridges and trust in response to those challenges which undermine Africa's march to progress and hope.

\section{The African predicament}

Africa's diverse religious and cultural resources are supposed to be assets, enriching the continent and its people. However, these diversities have often been transformed into contentious differences, tensions, conflicts and violence. Conflict and violence have become a major narrative of the African story. "One may even assert that the major current that runs through Africa, from North to South, East to West and Central is conflict and wars" (Aremu, 2010:549). It has to be noted, however, that causes of tensions, conflicts and violence are many and cannot be attributed solely to religion. Casimir et, al (2014:60), for example, give analysis of Boko Haram's violent attacks in the North Eastern part of Nigeria and intimate that its origin is rooted in the failure of political leadership. They argue that politicians created poverty conditions through the neglect of their duties, which forced young people unto the streets as beggars. These were later recruited as foot soldiers by the same politicians, who failed to honour their promises to them and abandoned them. With weapons in their hands, and finding a religious ideology which connects to their cause, they get recruited into an armed rebellious religious group to fight for their 'religious' rights. Odusola, A. et al (2017) have also argued that causes of most conflicts in Africa are attributable to inequalities and poverty, which act as pushers of social exclusion, manifesting eventually in unrest, instability and violence. ${ }^{3}$ These, coupled with other deplorable socio-economic conditions, corrupt political leadership and weak institutions, are found to be major actors in these situations. In the midst of these, certain individuals and groups seeking justice for themselves as well as political and economic power, tend to exploit religion to achieve their cherished agenda. Aremu (2010: 551), further, observes, that some of the conflicts, were due to the forceful creation of arbitrary borders by colonial powers, which failed to take into account the ethnic composition of African people; the action divided the same ethnic groups and brought together rival ones, preparing the grounds for ethnic friction and tensions. In this connection, he makes reference to inter-states conflicts arising from border and land disputes between Nigeria and Cameroon, Algeria and Morocco, Ethiopia and Somalia, Chad and Libya, Tanzania and Uganda, etc, to buttress his point. Worse still, the disruptive processes of globalization, manifesting in the imposition of Western cultural forms, have undermined African indigenous values which held communities together. The impact of globalization has been felt differently in various societies. In Africa and elsewhere, the influence of new technological communication and the incorporation of new market economies have disrupted communal life and ushered in various forms of tensions and suffering (Julio de Santa Ana, 1998: 14). All these have served as preparatory grounds for these diminishing life experiences to take place on the African continent. The point here is that there cannot be simplistic explanation to the conflict situations in Africa and that investigations, analysis and possible solutions to these problems must be holistic and authentic in approach. The question confronting Africa in the $21^{\text {st }}$ Century is that, in view of these multiple barriers in the way of African's quest for peace and harmony, where do we turn to for appropriate resources to respond to the problem? To this question, we shall soon turn for answers in this study.

These causes to violence in Africa notwithstanding, one can also observe, on the other hand, that there have been certain situations in Africa, where religion has been found to be instrumental, directly or indirectly, in festering conflicts. Awolalu (1991:118) makes reference to how Uthman dan Fodio introduced radical Islam in the Northern part of Nigeria in the $19^{\text {th }}$ Century and waged jihad, a holy war against all those who were unwilling to convert and those who converted but, held on to some of their indigenous African religious beliefs and cultural practices.

In addition, we have also identified the central place and role of religion in the individual and collective African life. Given the nature and pervasive influence of religion in African experience of life, this paper argues that religious communities still have an important role to play in providing answers to the problem of violence and unrests on the continent. The relevance for suggesting religious resources in addressing some of these challenges is evidence based. For example, the formation of African Union Interfaith Forum, is in realization that religion plays a crucial role in every aspect of the African life. This subject will be revisited later for further elaboration.

This paper is, therefore, proposing an interfaith approach that brings on board some of the rich African indigenous religious concepts and cultural values, found in the traditional social structures of extended family, which can build bridges and trust across divides.

The paper is, however, of the conviction that religion alone cannot do it, but an indigenous approach that sees life as a wholistic system is what is required in response to the challenges on the continent.

\section{Methodological Approach}

The study is primarily based on library research, and makes use of religious and sociological approaches in 
discourse and analysis. The conviction of this study is that in spite of what secularization theorists will want us to believe about the 'death' of religion in this globalization process, religion is very much alive and occupies the centre stage, especially, in many societies in Africa. In this respect, Magonet (2015:42) cites the key elements of Kung's theological basis for dialogue, which are important for this study as follows:

- No peace among the nations without peace among the religions.

- No peace among the religions without dialogue between the religions.

- No dialogue between the religions without investigation of the foundations of the religions.

These points mentioned above provide the support for the argument of this paper on the key role religions can play for peace making in Africa.

The study first, gives a brief background to the religious composition of Africa. Secondly, it examines the nature and dynamics of interfaith relations and the activities of interfaith groups in Africa. Some of the inherent weaknesses of certain existing inter-religious approaches are also discussed. A recommendation for an interfaith approach that can help address the challenge of conflict situations on the continent is made. The study admits that the nature and causes of conflicts on the continent are quite complex, bearing in mind the huge size of the continent. However, the paper argues that in view of the place and role of religion in most societies in the sub-Saharan Africa, an interfaith paradigm relevant to the African experience of life can help arrest some the challenges identified.

\section{Religious Background of Africa}

The Continent of Africa is now a home to various religious traditions and the dominant among these are African Traditional Religions (ATRs), Islam and Christianity. ATRs is the indigenous religion(s) embraced by the forbears of the present generation of Africans (Awolalu, 1991). It is the oldest among the three, the founders of which cannot be traced. Yet, it has suffered the most decline, being a victim of the missionary activities of Islam and Christianity. By 1900 , ATR was $58 \%$ of the population but dropped to $26.9 \%$ by 2000 . Although it is declining, it forms the basis of the cultural life of most Africans, religious or non-religious and it cannot, therefore, be ignored.

Islam has been in Africa for more than thousand years and in countries of the Sahara, it has become an indigenous religion. It has grown from about 32\% of Africa's population in 1900 to $40.3 \%$ by 2000 (Temple, 2001). Almost all the north African countries such as Morocco, Algeria, Tunisia, Egypt, Somalia etc. are Muslim majority states.

Christianity, on the other hand, is the newest, in terms of its presence on the continent, and yet, it has grown to be the fastest, from $9.21 \%$ in 1900 to about $46.58 \%$ in 2000 . With few exceptions, however, countries that are Christian majority, are located in the Southern, Central, Eastern Africa and in some West African states such as Ghana. We now look at the nature of interfaith engagements and dynamics in Africa, but before then, let us attempt a definition of the term dialogue.

\section{Definition of Dialogue}

In this study, we define dialogue to be a mutual conversation as well as relationships between people or groups of persons. It is thus understood in diverse ways: "as a mutual communication, as an attitude of respect and friendship, as a whole complex of interreligious relations..." (Dialogue \& Proclamation Document, 1991). Religiously, it can be an engagement between different sects of religious groups within the same tradition (intra-religious dialogue) or between different religious traditions (inter-religious dialogue). When it is officially organized, it takes place at the institutional levels, involving religious leaders or experts who wish to discover more about differences and commonalities in each other's religious tradition. For instance, when Pope John Paul addressed Muslims in Turkey, he stressed on the need for dialogue between Muslims and Christians by reminding them of the spiritual bond that unites the two religious traditions. ${ }^{4}$ The purpose of dialogue is to foster understanding and promote peace among diverse religious traditions and to foster harmony in the world. It can also take place among members of different faith traditions at the grassroot level, who share their lives together in family or community setting. Speaking on dialogue, Pope John Paul 11 (1991) defined dialogue as a witness of God's love for all humankind." In the same vein, Konrad Raiser (2001) emphasizes that dialogue within and between religions requires not just tolerance but respect for the other in his or her authentic relationship with the Holy. The other, whose culture and belief is different from mine has been created by God and is the object of his love. He/she is therefore to be respected as one with a right to worship, the way she/he chooses to express this and as one with dignity in dialogue relationship. Among the aims of dialogue is helping people of different religions to live together in peace and harmony, in a world that is, increasingly, becoming multi-cultural and multi-religious (Fitzgerald, 2003). ${ }^{6}$

\section{The Nature of Interfaith Relations and Dynamics on the Continent}

In giving a brief religious background to Africa, we discovered that religious plurality is an established fact on the continent, especially, as one observes the rapid growth of both Islam and Christianity, as well as other religious groups.

The interfaith relations in Africa, which constitutes our focus in this section is that which involves the three 
dominant religious traditions on the continent - ATRs, Islam and Christianity. Basically, about four trends of relationships can be identified:

i. There are countries in North Africa, referred to as the El Maghreb countries such as Algeria, Morocco, Tunisia, etc., which belong to the Arab League. In this part of Africa, Muslims are in the majority and in those contexts, there is no possibility of public sharing of one's religious beliefs besides Islam. Religious freedom here is restricted. Zandt (2011) makes a comparison of the nature of interfaith relation in such communities with what prevails in the Southern part of Africa. "In contrast to North Africa and the Middle East, religious freedom in large parts of southern Africa is generally respected." In Islam, religion is a way of life that extends into all aspects of life and "God is the sole legislator" (Dennis, 1994). This includes politics and governance. Religion in such areas is highly politicized, as Muslims do not separate religion from politics. To them systems of governance and political decisions are just expressions of the Muslim faith and the shar'ia, Islamic law is imposed.

ii. The second situation is where we have Muslim majority in Black African countries such as Senegal, Benin, Mali, Burkina Faso, etc. Even though in these countries it is not allowed for Christians and other religions to openly share their faith with the intention of converting Muslims, these communities are politically and culturally open to dialogue. In the 1960s for instance, the Muslim majority in Senegal voted for Leopard Sedar Senghor, a Christian as president and cooperated with him. Here, you can find Christians and Muslims in the same family, household, and community living together peacefully. In this place, the prevalence of secular state principles allows the indigenous religious and cultural values to mediate and create harmonious interfaith relations (Acquah, 2002). There are, however, some exceptions such as the case of Sudan and Northern Nigeria, where shar'ia, is imposed and radical Wahhabi Islamic practices create barriers for interfaith relationship in the communities.

iii. The third, has Christians in the majority such as Zaire, Burundi, Kenya, Ghana, etc., which serve as examples, and here, the dialogue process is open. These countries are secular states, where there is freedom of religion, without any preferred religious tradition by the state. Muslims and other adherents of other religions can witness to their faith publicly. Christian Councils have cordial relationship and collaboration with non-Christian religious bodies.

iv. There is the fourth, where countries have a strong presence of both Christians and Muslims. The dialogue relationship is determined by which group has the numerical advantage in a particular geographical region within that country. It is in this context that religious extremists exploit the situation in order to gain the upper hand. Many a time religion is used as the basis for establishing political parties and structures. Tanzania, Uganda, Congo, Sudan and Nigeria are some examples of this. Anglican Bishop Josiah Idowu-Fearon, commenting on this situation in northern Nigeria said, "Christians have no rights, religious pluralism does not exist, intermarriage is prohibited unless a Muslim man marries a Christian woman. No government patronage is given to Christians, and there is no public proclamation of the gospel" (Nkulu N'Sengha cited in Acquah, 2002). Religious relationship here is characterized by hatred and sometimes violence.

Due to these challenges, interreligious groups have made attempts to respond to these situations. For example, the Christian-Muslim Mutual Relations in Nigeria and the Interfaith Councils in Sudan and Congo are all involved in dialogue for peaceful co-existence.

Underlying some of these religious tensions in Africa is the problem of religious intolerance, which is rooted in exclusive claims and fundamentalism. The challenge here lies in the fact that most of the extremists come from radical separatist groups within both Christianity and Islam, and do not even recognize the authority of the religious leaders of their councils or traditions.

The situation is made worse by the recent infiltration and aggressive activities of certain radical religious groups in some African countries. For, example, an IS affiliate militant Islamic group carried out an attack on mosque worshippers on November 24, 2017 in northern Sinai, Egypt, killing 305 people, including 27 children (History.com Editors, 2017). ${ }^{7}$ This figure represents just what was recorded the time of reporting. The number of death victims was likely to go up, besides those who were injured. Similar atrocities have been carried out by other religious extremists such as El Shabaab, Boko Haram and others.

The challenges noted from the discussions make it imperative for a religious response in search of peace in the context of the continent's religious rifts and other conflict situations. This paper calls for efforts to be made in pursuance of an interfaith dialogue which addresses African needs. A relevant and mutual religious dialogue must engage the attention of religious groups on the continent for two main reasons: the first is that the activities of such radical and extremist groups bring untold hardships to the continent, worsening the already bad news published about the continent. Secondly, these groups which act in the name of religion undermine what the religious traditions really stand for and their credibility. In such situations, religious groups find themselves divided by conflicts that have been perpetuated by these extremists, who in the process, become strong opponents of religious actors who desire to build peace in these communities (Casmir et al, 2014). ${ }^{8}$ For these reasons, collaborative efforts 
by all stake holders, including religious groups, governments, NGOs, etc are required to address this menace. In this direction, one expect the ecumenical bodies and other interfaith groups in Africa to take the initiative.

It was mentioned earlier that, there are other areas in Africa where adherents of ATR, Islam and Christianity live peacefully with each other. One of the major factors, which account for this is the common African cultural values which bind the people together in these black African societies. These values, rooted in traditional African religions and culture, naturally foster dialogue of life in such African communities, where conditions allow religious freedom to flourish. In this sense, ATR serves to build bridges across faith traditions, especially, Christianity and Islam through the dialogue of life. In this sense, ATR(s) constitutes the necessary starting point for any meaningful interreligious dialogue in Black Africa (Nkulu-N'Sengha, cited in Acquah, 2002).

\section{Some Interfaith Organizations and Activities in Africa}

On the continent, official dialogue, with its Western theological and intellectual approaches has been employed, mostly, at the institutional level. This Western form of interfaith encounters has been organized through conferences, seminars and workshops to promote peace. The main actors in these engagements have been the global Christian ecumenical body, the World Council of Churches (WCC) and the Roman Catholic Church, in conjunction with All African Conference of Churches (AACC). Besides these, there are others, the activities and programmes of which are towards peace making on the continent. Some of these will also be discussed later.

Awareness and engagements in an organized form of interreligious dialogue in Africa could be, partly, traced to the period after the independence of several African states. This was the time when African cultural values were being revived and many African elite stressed that political independence must go hand in hand with religious independence. By this, attention was being drawn to the need to change the mindset of denigrating African indigenous values as inferior and irrelevant for life, especially, after experiencing the scars of colonization and negative attitudes of some European Christian missionaries.

This development affected the church's attitude to African culture and religions. A consultation was organized by AACC in Jan. 1966, at Immanuel College in Ibadan, Nigeria, which brought together a number of African theologians. The purpose was to reflect on how Christianity could relate to African culture and religion(s) (Amissah, 1969). This was against the backdrop of European cultural influence on the proclamation of the Christian gospel by Western missionaries in Africa.

Another contributing factor to the development of interreligious dialogue in Africa was the impact of Vatican II. Through the cooperation between the Pontifical Council for Interreligious Dialogue (PCID) and the WCC office on Inter-religious Relations (IRRD), an interreligious project was instituted in 2000 to explore Africa's contributions to the religious heritage of the world (Ucko, 2004). It was a document that was published by the then WCC sub-unit on Dialogue with people of Living Faiths ((DFI) after a consultation on ATRs, held in Mindolo, Zambia from $22^{\text {nd }}$ to $28^{\text {th }}$ September, which signaled this project (Ucko, 2004). As Ucko (2004) admitted, the Western world, and even WCC focus on Africa has been a negative narrative of failures, disappointments, conflicts, violence, etc. This joint project on Africa was a practical demonstration, on the part of Christianity, to employ interfaith dialogue to grant space to Africa for the exhibition of her religious and cultural contributions to the religious heritage of the world as an equal and deserving partner. In this way, the harm done to Africa's indigenous religious and cultural traditions through slavery, colonization, conscious or unconscious missionary and Western denigration of African identity, can be repaired to some extent. This and other interfaith initiatives placed responsibilities on immigrant religions in Africa to learn how to receive ATRs at the dialogue table and allow its indigenous resources to be relevant in addressing the challenges confronting the continent. The abovementioned developments have been instrumental in informing and shaping institutional forms of dialogue on the continent.

\subsection{Other Interfaith Engagements in Africa}

There are other interreligious bodies working to foster interreligious relations for common action and peace building in Africa besides the ones mentioned above. Examples of these are Ecumenical Association for Third World Theologians, the Project for Christian-Muslim Relations in Africa (ProCMURA), United Religions Initiative, African Council of Religious Leaders - Religions for Peace (ACRL - RfP), Regional Interfaith Councils and interfaith councils in some African countries. The Interfaith Council in Sierra Leone, for instance, has been very much involved in working for peace among the then warring factions in that country. The Christian ecumenical council and interfaith council of Sierra Leone, together with the national Christian council jointly organized a seminar from April 24 to 25, 2001. It was attended by both Muslim and Christian religious leaders from Guinea, Liberia and Sierra Leone. The religious leaders discussed the conflict and instability in the Mono River sub-region and pledged to work together for peace.

Space will not permit us to discuss all of them in detail here. However, the activities of two of them and a grassroot indigenous interfaith relations, referred to as 'dialogue of life' will be examined briefly to illustrate the extent to which some of their activities have been instrumental in fostering peace and sustainable living in some 
communities on the continent.

\subsubsection{ProcMURA}

The Programme for Christian-Muslim Relations in Africa (ProcMURA) was, initially, created in Accra, Ghana in 1959 as the "Islam in Africa Project." The organization, which is predominantly Christian, has the vision of, first, offering faithful witness to the Christian gospel in a pluralistic religious environment involving Christians and Muslims, and secondly, to enhance a constructive engagement between Christians and Muslims for the promotion of peaceful co-existence and holistic development of humankind. ${ }^{10}$

ProcMURA organized an interfaith consultation which took place in Lome, Togo from 13-18 Dec. 2000 in view of the emerging incidence of religious extremism. However, the consultation fell short as far as bringing together those who mattered most in such discussions were concerned. The representatives at this consultation were all Christians and this made it impossible for the consultation to benefit from the input of other religions, especially, Islam and African Traditional Religion(s). The lack of representation from other religious traditions hampered pertinent discussions on issues such as religious extremism, intolerance, conflicts, etc., and the collective religious efforts required to address them. The suggestion of Gobena (2001) at the consultation in response to this handicap is, therefore, very important in any approach to interfaith relations in Africa: "What I would like us to consider is whether we should not in the future invite people of other faith communities for a consultation where we can reason together what should be done to promote peaceful co-existence. I believe in this lies the approach to holistic and meaningful dialogue in Africa."

In trying to promote a meaningful inter-religious engagement on the continent, ProcMURA is often handicapped by its own internal structure and scope. Its predominant Christian composition and emphasis, sometimes, excludes important Islamic input in the entire process and activities. In addition to that, ProcMURA, focuses on Christian engagement with Islam to the exclusion of African Traditional Religion(s), which serves as an important mediation for the two immigrant religions.

\subsubsection{African Council of Religious Leaders - Religions for Peace (ACRL - RfP)}

The African Council of Religious Leaders - Religions for Peace (ACRL - RfP) is a continental coalition body which brings together different faith organizations, faith communities and African religious leaders and subregional and national interfaith councils to promote peace and well-being in the African continent. ${ }^{11}$ As a multifaith organization, it was established in 2002 in Nairobi, Kenya with the mandate to create platforms and networks for actors and different faiths to take common action in promoting harmony and sustainable progress for African. ${ }^{12}$ The objective is to make it possible for various religious groups in Africa to translate, through interfaith relations, their various ethos into moral and spiritual transformation. It seeks to partner AU and national governments in addressing critical issues on the continent such as economic development, HIV/AIDS, good governance and conflict transformation. ${ }^{13}$ In pursuance of the above-mentioned objectives, in the year 2010, for instance, the ACRL-RfP organized a consultation on the role of religious leaders and women of faith in peace and conflict transformation and Millennium Development Goals (MDGS) for Africa in Nairobi, from November 19-2 $1^{\text {st }} .{ }^{14}$

The ACRL - RfP has also been playing advocacy role in denouncing political violence in African countries. According to a statement released to Agenzia Fides (2018) and signed by His Eminence Cardinal John Onaiyekan, Archbishop of Abuja, Nigeria and Co-Chair of ACRL-RfP, the council condemned the use of brutal force against peaceful protestors in Khartoum by the transitional ruling military council in Sudan. ${ }^{15}$ The organization, further, launched an appeal for dialogue between the military rulers and the opposition alliance in order to create conditions which would make it possible for a government that could meet the need of the people of Sudan to be formed. ${ }^{16}$

The strength in the activities of ACRL - RfP, in particular, lies in the ability to use its networks to carry its activities from top levels down to the grassroots. This involvement brings on board the insights and wisdom of African religious leaders as well as the sharing of experiences of those who live in real conflict situations within family and community settings. The participants in such interfaith relations are fellow Africans of diverse religious affiliations. In this respect, the dialogue approach connects well with the indigenous inter-religious model referred to as 'dialogue of life'.

However, the composition of this council like other interfaith religious institutions, is predominantly Christian and Muslim. Intentional created structures to include ATRs is still missing.

\section{Dialogue of life}

We now turn our attention to an important indigenous interfaith model that has flowed naturally from the African extended family structures and community sense of belonging referred to as 'dialogue of life'. This indigenous approach, has been on-going in family and community settings in most communities in black Africa. In this, people from different religious and cultural backgrounds live and share their lives together. Africans, especially, those in the sub-Sahara do not see dialogue as conceptual arguments or theological discussions between two parties. In indigenous African understanding, "To be born into African society is to be born into a culture that is intensely and pervasively religious and that means, and requires participating in the religious beliefs and rituals of the community (Gyekye, 1996). Dialogue for them, is a process of fruitful exchange of beliefs, practices, and concepts 
through living together and working together for the well- being of the community. Elizabeth Amoah (1998) was right when she said, "differing religions in Africa do encounter each other. One of the several consequences of such an encounter has been an inevitable exchange." ${ }^{17}$ In this respect, ATRs has played a major role in transforming the two missionary religions - Christianity and Islam - and this has been done by confronting both with the decisive issue of indigenization (Amoah, 1998).

This exchange has been going on in terms of relationship among these three religions, made possible by the mediation of traditional African beliefs and cultural values. These values stress on accommodative, communal and pragmatic aspect of religion and the concept of religion as a tool for promoting harmony and progress in life. In view of this relevance, Mbon (1991) makes a call for a return to African traditional ethical principles based on communal well-being and not for the privileged few. In this respect, ATR serves to provide essential tool for sustainable interfaith relationship, certain African communities. Events such as festivals, weddings, child naming, funeral, etc are celebrated together by all. In view of this, one can appreciate, the extent to which, the marginalization of these indigenous values by European colonizers and some Christian missionaries in African has seriously undermined the indigenous contribution in peace building efforts in Africa. The impact of this has been a psychological and emotional disorientation, with its cultural alienation, resulting in the failure of Africans to resolve and bring from within their indigenous religious and cultural resources in response to their predicament. Now, some African Muslims and Christians have been made to believe that to be accepted and recognized as a 'true' Muslim or Christian, you need to break with your indigenous past since it is tainted with 'evil' and has no relevance for life.

One major handicap of this paradigm of interfaith relationship is the lack of education at the grassroots regarding the activities and intentions of radical and extremist religious groups. Many of them are, ignorantly, taken for granted and manipulated by the deceptions of certain opportunistic religious groups and their leaders. These groups, often, project themselves as zealous religious followers and are able to use community religious affiliations as tools in violent situations to achieve their selfish agenda.

\section{Limitations of Western Approaches to Interfaith Relations in Africa.}

In Africa, the religious life, as noted in our discussions, is about community participation in events and activities with their associated religious rituals, which bring together people of diverse backgrounds. Abimola (1991) has observed, for instance, among the Yoruba that, festivals and family solidarity brought Muslims and Christians together. Most of the institutional forms of dialogue in Africa discussed above, reflect the Western institutional model of dialogue. As helpful as this may be, the institutional level of engagement has major limitations within the African setting in equipping various African community members to deal with tensions and conflicts resulting from religious differences as well as certain socio-economic deficiencies. Institutional form of dialogue mostly, involve religious leaders and scholars while most ordinary people, who really encounter each other in family and community interfaith relations are excluded from such engagements. Most often, the outcome of such institutional interactions fails to seep through to the grassroot levels. Yet, it is at this level of society that seeds of discord and mistrusts are sewn, which mature into community dimensions.

There is also the failure of ecumenical bodies to engage the indigenous context in a mutual interfaith relationship and with respect. This places a limitation on sustainable interfaith efforts in Africa. Interfaith relations in Africa cannot be meaningful unless it is informed by the needs of African communities. In planting the church in Africa, for instance, European missionary approaches as well as colonial project became instrumental in dividing Africans into denominational groups and artificially created ethnic boundaries. Some aspects of these legacies still live on and negatively affect Africans' search for unity. For example, churches established by Western missionary agencies have still not been able to bring on board those instituted by indigenous Africans (African Independent Churches). In this respect, the African Independent Churches which reflect aspects of African indigenous religious beliefs are excluded from national and regional ecumenical bodies in Africa. This invariably, hampers the indigenous contribution in interfaith efforts to promote peace in the continent.

With these observations in mind, we shall now make some suggestions, based on the findings from our discussions and analysis so far. These suggestions will attempt to address how indigenous African religious contributions for building bridges and trust across religious divides in Africa can be promoted through interreligious dialogue for peaceful and sustainable living.

\section{Suggestions for a Relevant and Meaningful Interfaith Dialogue in Africa}

This section will discuss three main suggestions to be acted upon in the interfaith relationships to help build bridges and trust for the promotion of sustainable living and peace in Africa. The conviction of this paper is that the pursuit of these action plans can help transform the fortunes of the African continent for peace and hope.

\subsection{Creating a Space for Indigenous African Religious Voice in Interfaith Relations}

Right from the time Islam and Christianity entered Africa, it is the two immigrant religions that have been doing 
the taking through institutional forms of dialogue, in which the host has no voice. This kind of one-sided dialogue in which the African religious and cultural heritage has been treated as an inferior non-participant, has prevented Africa from using her divine-given gifts and resources to chart a path for her own destiny and progress.

Puritanical Islam also felt that African indigenous religious expressions in Islam were 'fetish,' which needed to be cleansed from 'pure Islam.' In North Eastern Nigeria, Uthman dan Fodio, therefore, waged a jihad against converts to Islam who were still holding on to some of their indigenous religious and cultural practices (Awolalu, 1991). Williamson (1974) has also observed that missionary Christianity in Africa created a sense of shame within African converts of their indigenous and religious past. In terms of interfaith dialogue, Africa has not been allowed, and is still not given a voice to offer her religious and cultural contributions in response to life challenges in Africa and the world. The missionary venture in Africa by Islam and Christianity, tried to keep ATRs and its values at bay, but did not succeed, since the vitality of the indigenous religious and cultural heritage continues to permeate in all religious expressions, including immigrant religions on the continent (Ucko, 2004). Ucho (2004) rightly observed that African religiosity is "...lived, it is experienced, and it is integrated and present not only in African Traditional Religions but deep inside Christianity and in Islam.

This paper does not intend to present an exotic view of African Traditional Religions and cultural practices. There is no doubt that in the history of African people, some of their religious beliefs and practices have been oppressive, especially, against women and children and the same goes with other religious traditions and cultures of the world. The paper is, however, arguing that there are certain rich and life-affirming African religious and cultural values, which must be allowed to flourish, develop and to build the capacity for addressing Africa's needs as well as certain global challenges. This vision has to be realized, this time, through the agency of African Christian and Muslim converts as well as African converts to other religious traditions, who embody in themselves these indigenous resources. This is a call for them to remove interfaith barriers which stand in the way of ATRs. The early missionaries of Islam and Christianity can be excused for looking down on ATRs, partly, due to ignorance, but the same cannot be said about African converts to immigrant religious traditions, some of whom are now leaders of these religious groups.

The study, therefore, calls for a constructive and relevant inter-religious dialogue which takes into serious account the dynamics of the indigenous religious mediation and which informs dialogue of life among members of various religious communities in African societies.

\subsection{The Indigenous African Sense of Community and Family}

We have discussed how various conditions of socio-economic deprivation, religious, political and ethnic differences have provided fertile grounds for conflicts and violence to thrive in Africa. Pobee (1991:56) has made reference to the tragedy of divisions within Christianity which was replicated by European missionary agencies in Africa. Acquah (2002: 12) has also noted that different political groups and their leaders also tend to exploit the different ethnic differences in African societies to create divisions which serve their political agenda. Addressing the causes of conflicts in Africa, Aremu (2010: 551) has, further, identified ethnicity and political discrimination which are being practised against certain minority groups in the continent. He correctly warned that ethnicity can be a great potential for separatist activities as it creates feelings of suspicion, hatred and distrust among African people.

We have, on the other hand, observed how the African communal understanding of life engenders a strong bond and sense of belonging, integration, inclusiveness and common identity among Africans. Olugbenga Olagunju (2013:43) commented on these indigenous communal values as follows: "The African environments are communal in nature. Their orientations tend toward peaceful co-existence within the community. African communities are known for communal cooperation, respect and tolerance of one another not until the advent of Islam and Christianity." Of course, one must as well recognize the impact of globalization, with the imposition of Western cultural forms as, partly, responsible for the on-going undermining of African communal values and ethics, leading to the disintegration of Africa communities. In view of this indigenous bonding, the Most Rev Francis Lodonu (2011), for instance, has called for the sustenance of the African extended family system through the promotion of "family feast" and family re-unions. He described the extended family system as an essential aspect of the Ghanaian culture which should not be allowed to be erased by the changing times. This indigenous contribution to life through extended family structures and communal relations provide a solid foundation for interfaith relations and can inform and shape inter-religious engagements in Africa for peaceful co-existence.

A dialogue approach that recognizes some of the indigenous African resources that have held communities together over the years is being commended for both leaders and immigrant religious traditions in Africa. A serious commitment to engage this indigenous past is, an essential step for Africans. This will make it possible for them to make use of the insights from their traditional heritage as well as those found in their newly acquired faith traditions to mount a collective and meaningful response to what confronts Africa in the $21^{\text {st }}$ Century and beyond.

\subsection{Indigenous African Understanding of Religion and its Role in Life}


In the African experience of life, religion is understood as that which unifies and enhances the collective and individual well-being. Oosthuizen (1991: 41) pointed out this religious relevance in ATRs: "In ATRs, ontological harmony is of primary importance." Olagunju (2013: 40) has also observed that the indigenous religious understanding provides a common ground for sharing what is dear to people. He noted that in various African communities, there is love and sharing among the various religious adherents and participation in Muslim, Christian and traditional religious festivals. For the African, religious plurality is a blessing because it provides complimentary resources for dealing with various challenges in life.

This religious attitude of the African people accounts for the reasons why the two immigrant religious traditions - Christianity and Islam - thrived on the continent. The traditional religious systems are inclusive and pluralistic in orientations and worldviews. Africans recognized the fact that the God which Islam and Christianity proclaimed is the same God which the traditional people were worshipping and so when they encountered Islam and Christianity, dialogue with and toleration of these new religions did not present a difficulty (Olagunju, 2013:47). Indigenous religious orientation and cultural practices of Africans have mediated in interfaith relations, especially, in black Africa communities to foster harmonious living over the years. In the midst of prevalence of religious extremism in various Africa societies, this paper argues that dialogue of life has to be strengthened at the grassroot. This can be done through interfaith organizations such as ACRL-RfP and interfaith councils, among others. This can provide the key for countering foreign radical religious ideas which tend to divide the people and to breed hatred and mistrust among them.

In addition, indigenous Africa concept of community embraces both human and non-human. There is a sense of human beings' close relationship with nature in this religion. Humanity, animals and plants have "their own existence and place in the universe as independent parts of a whole (Turaki, 1999: 34). The indigenous belief that nature is filled with the various manifestations of the divine explains the respectful and reverent treatments of certain elements of nature such as rivers, forest reserves (sacred groves), stones, etc., some of which are regarded as totems. These African traditional resources can provide strong moral and ethical grounds for dealing with critical environmental issues confronting the continent.

Various societies in Africa, have unfortunately, come under the strong influence of certain Western values through colonization, Christian missions and other processes of globalization. The Western view stresses that humanity is independent and has separate and distinct existence from the rest of nature, while Christian anthropocentric understanding of creation, also tends to view nature as an object to be exploited, especially, in an age driven by the insatiable desire to consume.

In view of these realities, this paper calls for an interfaith engagement that explores and takes into serious account the indigenous African holistic religious view of community, which can provide resources for addressing some of the environmental crises confronting the continent and the world.

Finally, we noted how failed political systems and bad governance have created oppressive social conditions, serving as fertile grounds for religious radicals and extremist to exploit for their selfish ends. Africans have a strong utilitarian orientation and pragmatic religious purposes. That is, religion is supposed to build lives and communities and not to destroy. Most political leaders and those in governance are affiliated to various religious communities. It is the responsibility of religious leaders and their communities in Africa to engage their members in such positions and to inculcate in them religious ethics of service and honesty. Such moral resources can help in addressing the problem of greed, selfishness and corruption that have virtually become the norm in most African societies. This can be done through interfaith platforms such as the African Union Interfaith forum at national and community levels with the involvement of ACRL-RfP, the outcome of which can be taken to the grassroots. In this regard, insights official forms of dialogue can be shared with various religious adherents at the grassroots.

The conviction of this paper is that an interfaith approach that makes it possible for indigenous African religions to make ethical contributions to the current crises in Africa's environmental, political and governance issues can help transform the negative narrative about Africa's image. The indigenous understanding of the pervasive influence of religion in life provides the grounds for this to happen.

\section{Conclusion}

Today new forms of destructive forces such as radical religious ideologies, corrupt political leadership, economic domination by Western powers and Multi-national companies continue to deplete Africa and create conditions which divide and keep African apart. The realities of the impact of such religious and socio-cultural assault manifests in various forms of conflicts on the continent, preventing Africa from asserting herself on the road to progress, harmony, sustainable and peaceful co-existence. In view of this huge challenge, Africans need to rediscover themselves as one people bound together by their communal values for existence, embedded in extended family ties. With these, Africa is capable of responding to extremist and radical religious ideas from outside which disrupts her efforts for relevance in life. An important contribution from indigenous African religious and cultural system that can help build bridges and trust for peace and sustainable living is the concept and value of communalism. In this indigenous understanding, 'complementary interrelatedness, which makes it 
possible for one to see himself/herself in others is stressed (UKESSAYS, 2016). ${ }^{18}$ This counters the challenge of absolute religious claims and exclusive stances in the midst of religious plurality, which extremists and radicals have exploited to perpetuate violence and inflict suffering on innocent people. In the midst of disintegrative forces in Africa, the continent needs that communal sense of belonging in order to hold societies together, impressing upon individuals and religious actors that the only right action is that which promotes the welfare of the entire community, and not, the interests of certain individuals or sectional ambition of any particular religious group.

This study has demonstrated that an interfaith approach that engages the indigenous and cultural context for building bridges and trust can be a vital response to counter divisions, stereotypes and destructive ideological weapons in the continent. In the midst of forces of disintegration that are impacting African societies, the continent needs resources which build social cohesion by building bridges and trust among the people. This can be found in African indigenous religious and cultural values, which need space and voice in interfaith relationships. This point was strongly affirmed by Pope Paul II when he addressed Ivorian students at Yamoussoukro. He told them that in indigenous African religious beliefs and cultures are "real treasures from which you can and must draw something new for building up your country, on an original and typically African model, made up of harmony between the values of its cultural past and the most acceptable elements of modern civilization (Pope John Paul II, 1980). It is time for the people of Africa, especially, Christians and Muslims to help change the negative image and narrative that have been associated with the continent all this while by giving a space and voice to indigenous religious system and values. This can be done as Africans dig from their inner dispositions of those indigenous religious and spiritual traditions which made it possible for Islam and Christianity and other faith traditions to find this continent as their home.

The author declared no conflict of interest with regard to this study, authorship and publication of the article. He also did not receive any funding for this research work, authorship and publication of this article.

\section{ORCID ID}

Francis Acquah https://orcid.org/0000-0002-5439-3431

Notes

See ht tps://www.pewforum.org/2015/04/02/sub-saharan-africa/ (accessed on 13 June, 2010)

${ }^{2}$ See https://au.int/en/newsevents/20181113/3rd-african-union-interfaith-dialogue-forum, (accessed on May 24, 2020)

$3 \mathrm{See}$

https://www.researchgate.net/publication/321627542_Inequality_intensity_and_poverty_drive_conflicts_in_subSaharan Africa (accessed on May 25, 2020)

${ }^{4}$ Scarboro Missions (2010). Pope John Paul II- Interfaith Giant. Available at:

https://www.scarboromissions.ca/interfaith-dialogue/the-church-dialogue/pope-john-paul-ii-interfaith-giant

(accessed on 12 June 2020). Pope John Paul II made this statement when addressing Muslims in Turkey.

Google Scholar

${ }^{5}$ Vatican. 1991. Recognize the Spiritual Bonds which Unites Us. Rome: Vatican Publication.

https://www.bc.edu/content/dam/files/research sites/cjl/texts/cjrelations/resources/articles/fitzgerald Oct03.htm, (accessed on June 2, 2020). An address he delivered by Fitzgerald, Michael (2003) at Trinity College in Washington on October 25, 2020

${ }^{7}$ See https://www.history.com/this-day-in-history/terrorist-attack-sinai-mosque-egyp (accessed on November 25, 2017)

${ }^{9}$ See https://www.globalministries.org/update_from_programme_for_christ_1_10_10_2014_1115,(accessed July 13, 2017).

${ }^{10}$ See https://www.globalministries.org/update_from_programme_for_christ_1_10_10_2014_1115, (accessed on July 13, 2017).

${ }^{12}$ Refer to https://berkleycenter.georgetown.edu/organizations/african-council-of-religious-leaders, (accessed on May 28, 2020)..

${ }^{13}$ See https://berkleycenter.georgetown.edu/organizations/african-council-of-religious-leaders, (accessed on May 25, 2020).

${ }^{14}$ See https://berkleycenter.georgetown.edu/organizations/african-council-of-religious-leaders, (accessed on May 28, 2020).

${ }^{15}$ See http://www.fides.org/en/news/66172, (accessed on June 7, 2020).

${ }^{16}$ See http://www.fides.org/en/news/66172, (accessed on June 7, 2020). 
${ }^{17}$ See http://iicao.org/iic-resources/lectures/african-indigenous-religions-and-inter-religious-relationship/, (accessed on May 24, 2020). Elizabeth Amoah presented this paper at an autumnal IIC lecture on 22 October, 1998 in the Council Room at Mansfield College, Oxford.

${ }^{18}$ Seehttps://www.ukessays.com/essays/theology/applying-the-african-communalism-theology-religionessay.php (accessed on July 13, 2020)

\section{Reference}

Acquah, Francis (2013), The Impact of Indigenous Religious and Cultural Values on Christian-Muslim Relations from 1920-2012 Saarbrucken: Scholar's Press.

Dennis., Frederick M (1994), An Introduction to Islam (2 ${ }^{\text {nd }}$ edition), New York \& Oxford: Macmillan Publishing Company.

Williamson, SG (1974), Akan Religion and the Christian Faith. Accra: Ghana University Pres.

Amissah, S. H. (1969), "Forward", in Kwesi A. Dickson \& Paul Ellingworth (eds) Biblical Revelation and African Beliefs. London: Lutterworth. Pp. vii-viii.

Awolalu, Joseph O. (1991), "The Encounter Between African Traditional Religion and Other Religions in Nigeria”, in Olupona Jacob K. ed. African Traditional Religions in Contemporary Society. New York Pp. $111-118$

Oosthuizen, Gerhadus C (1991), “The Place of Traditional Religion in Contemporary South Africa”, in Jacob K. Olupona,Jacob K (ed) Traditional African Religions in Contemporary Society. New York: paragon House. Pp. 35-50.

Olagunju, Olugbenga (2013), "Globalization and Inter-Religious Dialogue in African Cultural Context”, Journal of Studies in Social Sciences Volume 2 (1): 31-52.

Google Scholar

Samptkumar, R. (2004), "Promoting Human Rights and Peace - The Role of Religion in Current Dialogue", 43: 19-23

Sarbah, Cosmos E. (2016), "Interrogating the Approaches of Christian- Muslim Encounters in West Africa", Journal of ecumenical studies vol. 51 (3): 367-385.

Casimisr, A. et al (2014), "Religion, Violence, Poverty and Underdevelopment in West Africa: Issues and Challenges of Boko Haram Phenomenon in Nigeria", Open Journal of Philosophy, Vol 4, No 1, 60. DOI: 10.4236/ojpp.2014.41009

Google Scholar

Mbon, Friday M (1991), "African Traditional Socio-religious Ethics and national Development: The Nigerian Case" in Olupona, JK (ed) African Traditional Religions in Contemporary Society. New York. Pp. 101-110.

Abimbola, Wande (1991), "The Place of African Traditional Religion in Contemporary Africa: Yoruba Example" in Olupona, Jacob K (ed) New York Paragon House. Pp. 51-58

Ucho, Hans (2004), "Africa's Contribution to the Religious and Spiritual Heritage of the World", Current Dialogue 44. December. Geneva: WCC publication Pp. 4-8

Magonet, Jonathan (2015), "Growth of Interfaith Dialogue", European Judaism Volume 48, Number 2, Autumn 2015: $38-45$

Doi:10.3167/ej.2015.48.02.07 (Online)

Google Scholar

Sarbah, Cosmas E. (2016), "Interrogating the Approaches of Christian- Muslim Encounters in West Africa in Journal of ecumenical studies", 51 (3), 367-385

Appleby, Scott R (2001), The Ambivalence of the Sacred: Religion, Violence and Reconciliation, New York, Oxford: Rowman \& Littlefield Publishers, Inc.

Aremu, Johnson O (2010), "Conflicts in Africa: Meaning, Causes, Impact and Solution”,. An International MultiDisciplinary Journal, Ethiopia Vol 4 (4), No.17. October: 549-560

Google Scholar ISSN 2070-0083 (Online)

African Union (2018), "The $3^{\text {rd }}$ African Union Interfaith Dialogue Forum". Available at: https://au.int/en/newsevents/20181113/3rd-african-union-interfaith-dialogue-forum, (accessed on May 24, 2020)

Google Scholar

Zandt, Maria.( 2011), "THE SITUATION OF CHRISTIANS IN SUB-SAHARAN AFRICA". Available at: ://C:/Users/user/Documents/The\%20Situation\%20of\%20Christians\%20in\%20SubSaharan\%20Africa\%20(Pdf).pdf (accessed on Ma24 May 2020.

Google Scholar

UKESSAYS (2016), “Applying The African Communalism: Theology Religion Essay". Available at: https://www.ukessays.com/essays/theology/applying-the-african-communalism-theology-religion-essay.php (accessed on July 13, 2020) 
Google Scholar

Turaki, Yusufu (1999) Christianity and African god's: A Method in Theology (Nairobi: IBS-Nig. Press.

Odusola, A. et al (2017), Inequality intensity and poverty drive conflicts in sub-Saharan Africa. Available at: https://www.researchgate.net/publication/321627542_Inequality_intensity_and_poverty_drive_conflicts_in sub-Saharan_Africa (accessed on May 25, 2020)

Google Scholar

Recognize the Spiritual Bonds which Unites Us (1991), Rome: Vatican Publication.

Pobee, John S (1991), Religion and Politics in Ghana, Accra: Asempa Publishers.

Temple, Arnold C (2001), Christianity and Peoples of Other faith Communities, Nairobi: AACC Publication.

Dialogue and Proclamation Document No.42 (1991), Rome: Vatican Publication.

Christianity and People of Other Faith Communities (2001), Nairobi: ACC Publication.

Ghana News Agency (2011), "Bishop Lodonu calls for celebration of "family feast". Available at: https:/www.ghanaweb.com/GhanaHomePage/NewsArchive/Bishop-Lodonu-calls-for-celebration-offamily-feast-215105 (accessed on 15 July 2018).

Google Scholar

Fitzgerald, Michael (2003), "Evangelization and Interreligious Dialogue". Available at: https:/www.bc.edu/content/dam/files/research_sites/cjl/texts/cjrelations/resources/articles/fitzgeraldOct03.h tm (accessed on July 11, 2020)

Google Scholar

ProcMURA (2014), “Global Ministries' Update from Programme for Christian-Muslim Relations”. Available at: https://www.globalministries.org/update_from_programme_for_christ_1_10_10_2014_1115, cited $13 / 7 / 2017$

Google Scholar

History.Com Editors (2017), "Terrorists attack mosque in Sinai". Available at: https://www.msn.com/enus/news/world/egypt-raises-death-toll-in-sinai-mosque-attack-to-305/arBBFC4Ss?li=BBmkt5R\&ocid=spartandhp (accessed on 25 November 2017

Google Scholar

Nkulu-N'Sengha, Mutombo (1990), “Interriligious Dialogue in Black Africa among Christianity, Islam and African Traditional Religion,” Journal of Ecumenical Studies 33 no. 4, Philadelphia: Temple University, 1966, pp. 528-56

Google Scholar

Amoah, Elizabeth (1998), “African Indigenous Religions and Inter-Religious Relationship". Available at: http://iicao.org/iic-resources/lectures/african-indigenous-religions-and-inter-religious-relationship/, (accessed on 24 May, 2020).

Google Scholar

Raiser, Konrad (2001) A call to Dialogue. Current Dialogue, 36, Geneva: WCC Publication, 43- 49

"Major Issues in the Study of African Traditional Religion", in Olupona Jacob K (ed) African Traditional Religions in Contemporary Society. New York. Pp. 25-33.

Magesa, Laurenti (1998) African Religion; The Moral Foundations of Abundant Life. Maryknoll \& New York: Orbis Books

ACRl-RfP (2020), “African Council of Religious Leaders - Religions for Peace”. Available at: https://www.acrlrfp.org/ (accessed on 10 June 2020).

Google Scholar

Berkley Centre (2010), “African Council of Religious Leaders - Religions for Peace". Available at: https://berkleycenter.georgetown.edu/organizations/african-council-of-religious-leaders (accessed on 28 May 2018)

Google Scholar

Pew Research Centre (2015), "The Future of World Religions: Population Growth Projections, 2010-2050". Available at: https://www.pewforum.org/2015/04/02/sub-saharan-africa/ (accessed on 13 June, 2020)

Google Scholar

Agenzia Fides (2019), “AFRICAN/SUDAN - African religious leaders condemn the brutal suppression of protests in Sudan”. Available at: http://www.fides.org/en/news/66172 (accessed on 7 June 2020).

Google Scholar

Gyekye, Kwame (1996) African Cultural Values: An Introduction. Accra: Sankofa Publishing Company.

Julio de Santa Ana (1998), "Is a Sustainable Society Possible in the Context of Globalization?", in Julio de Santa Ana (ed.), Sustainability and Globalization. Geneva: WCC Publication, 1-22

Kilaini, Method (2001), "Ecumenism in a Multi-Religious Context", The Ecumenical Review 53 (3). Geneva: WCC Publication, 357-365.

Acquah, Francis (2002), Ecumenical and Inter-religious Dialogue in Ghana: Prospects and Challenges for 
Promoting Peace and Reconciliation, unpublished M. A. thesis. Faculty of Arts: University of Geneva.

Ghana (U.S. Department of State, Washington, Dc (1999), “Annual Report on International Religious Freedom." Available at: http://www.state.gov/www/global/human_rights/irf/irf_rpt/1999/irf_ghana.html (accessed on May 14, 2016).

Google Scholar

Author Biography

Francis Acquah

Francis Acquah is a lecturer at the Methodist University College Ghana and holds his joint $\mathrm{PhD}$ in Theology from the Hartford Seminary, Harford, Connecticut in the US and the University of Exeter, Exeter in the UK. His area of specialization is Religion and Ethics, with deep interest in Comparative Religion, Moral Leadership and Interreligious Relations. He is currently the Acting Head of Department in the Department of Educational Studies. 